Correspondence

Wen-Jun Li

wjli@ynu.edu.cn or liact@hotmail.com

\section{Plantactinospora endophytica sp. nov., an actinomycete isolated from Camptotheca acuminata Decne., reclassification of Actinaurispora siamensis as Plantactinospora siamensis comb. nov. and emended descriptions of the genus Plantactinospora and Plantactinospora mayteni}

Wen-Yong Zhu, ${ }^{1} \dagger \mathrm{Li}$-Xing Zhao, ${ }^{1}+$ Guo-Zhen Zhao, ${ }^{1}$ Xue-Wei Duan, ${ }^{1}$ Sheng Oin, ${ }^{2}$ Jie Li, ${ }^{3} \mathrm{Li}-\mathrm{Hua} \mathrm{Xu}^{1}$ and Wen-Jun $\mathrm{Li}^{1,4}$

${ }^{1}$ Key Laboratory of Microbial Diversity in Southwest China, Ministry of Education and Laboratory for Conservation and Utilization of Bio-Resources, Yunnan Institute of Microbiology,

Yunnan University, Kunming 650091, PR China

${ }^{2}$ The Key Laboratory of Biotechnology for Medicinal Plant of Jiangsu Province, Xuzhou Normal University, Xuzhou, Jiangsu 221116, PR China

${ }^{3}$ Key Laboratory of Marine Bio-resources Sustainable Utilization CAS, RNAM Center for Marine Microbiology, Guangdong Key Laboratory of Marine Materia Medica, South China Sea Institute of Oceanology, Chinese Academy of Sciences, 164 West Xingang Road, Guangzhou 510301 , PR China

${ }^{4}$ Key Laboratory of Biogeography and Bioresource in Arid Land, Chinese Academy of Science, Xinjiang Institute of Ecology and Geography, Chinese Academy of Sciences, Ürümqi 830011 , PR China
The genus Plantactinospora was described by Qin et al. (2009) with Plantactinospora mayteni as the type species.

†These authors contributed equally to this work.

The GenBank/EMBL/DDBJ accession number for the 16S rRNA gene sequence of strain YIM $68255^{\top}$ is GQ494033.

Four supplementary figures are available with the online version of this paper.
Shortly after the description of the genus Plantactinospora, the genus Actinaurispora was proposed with Actinaurispora siamensis as the type species (Thawai et al., 2010). At present, each of the two genera comprises only a single species. In this study, phylogenetic trees based on $16 \mathrm{~S}$ rRNA gene sequences of the type strains of the genera in the family Micromonosporaceae showed that these two genera belonged to one cluster. The main chemotaxonomic 


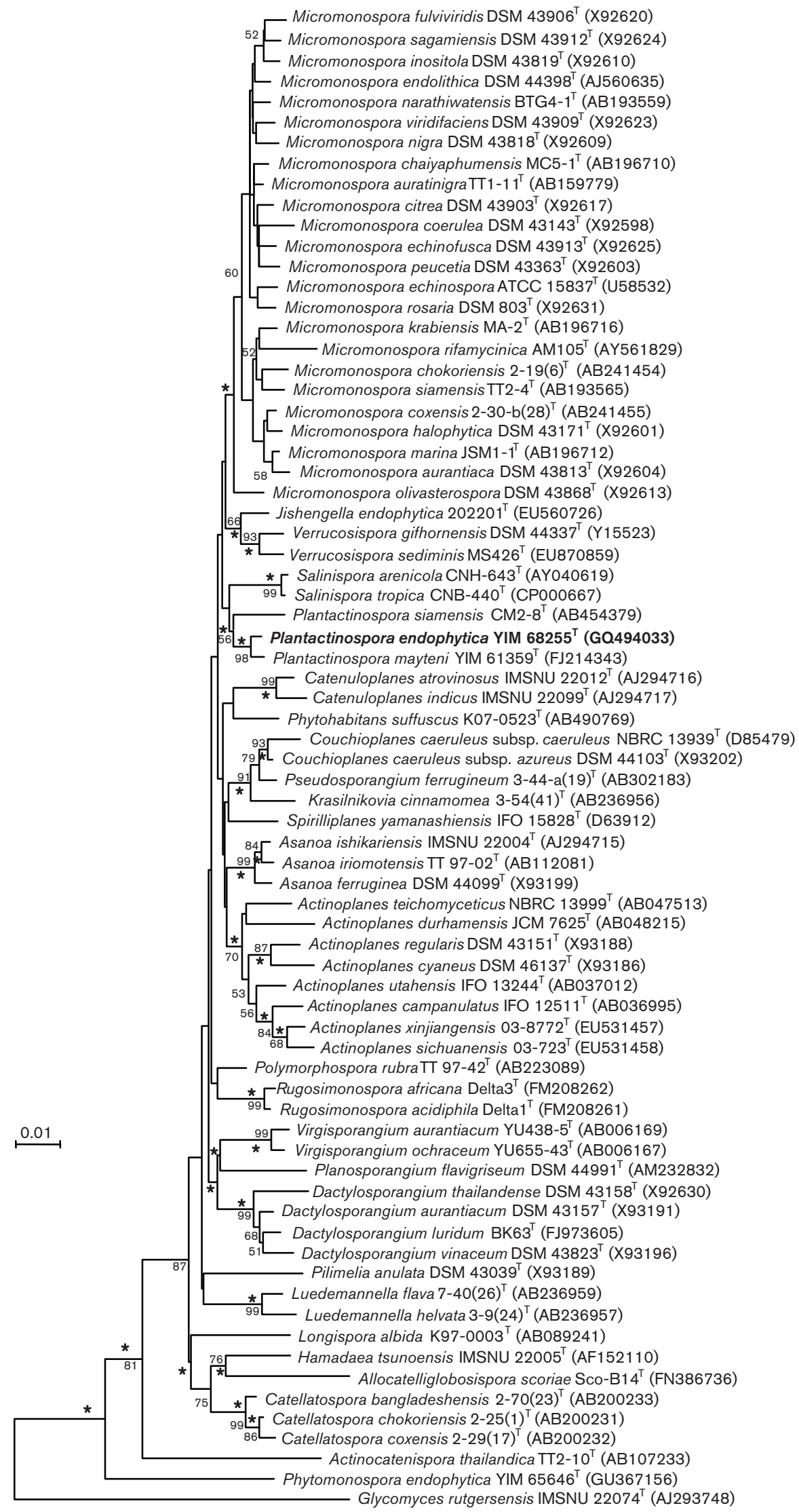


Fig. 1. Neighbour-joining tree based on $16 \mathrm{~S}$ rRNA gene sequences (1410 bp, by omitting unaligned regions) showing the relationships between strain YIM $68255^{\top}$ and related members of the family Micromonosporaceae. Bootstrap values ( $\left.>50 \%\right)$ based on 1000 replicates are shown at the branch nodes. Asterisks indicate that the corresponding branches were also recovered in trees generated with the maximum-parsimony and maximum-likelihood methods. Glycomyces rutgersensis IMSNU $22074^{\top}$ was used as the outgroup. Bar, 0.01 substitutions per nucleotide position.

differences between these two genera are reported to be the whole-cell sugars (Ara, Gal and Xyl in Plantactinospora and Gal, Man and Xyl in Actinaurispora), major menaquinones [MK-10 $\left(\mathrm{H}_{6,8,4}\right)$ in Plantactinospora and MK-9 $\left(\mathrm{H}_{6}\right)$, MK$10\left(\mathrm{H}_{6}\right)$ in Actinaurispora] and the fatty acid type $(2 \mathrm{~d}$ in Plantactinospora and 3b in Actinaurispora) (Qin et al., 2009; Thawai et al., 2010). During the course of investigating endophytic actinomycetes from medicinal plants in Yunnan province, south-west China, strain YIM $68255^{\mathrm{T}}$ was isolated from the leaves of healthy Camptotheca acuminata Decne., a Chinese traditional medicine plant. On the basis of $16 \mathrm{~S}$ rRNA gene sequence analysis, this isolate fell phylogenetically within the family Micromonosporaceae and clustered with P. mayteni YIM $61359^{\mathrm{T}}$ and A. siamensis CM2$8^{\mathrm{T}}$. In order to determine the phylogenetic and taxonomic relationships between strains YIM $68255^{\mathrm{T}}$, P. mayteni YIM $61359^{\mathrm{T}}$ and $A$. siamensis $\mathrm{CM} 2-8^{\mathrm{T}}$, their morphological, physiological and chemotaxonomic characteristics were determined.

Healthy leaves of $C$. acuminata Decne. were washed in running water to remove soil particles and sterilized by an established procedure (Li et al., 2008). After being surfacesterilized, the samples were sliced into pieces, followed by plating on TWYE agar (containing $0.25 \mathrm{~g}$ yeast extract, $0.5 \mathrm{~g}$ $\mathrm{K}_{2} \mathrm{HPO}_{4}$ and $18 \mathrm{~g}$ agar per litre of tap water, $\mathrm{pH} 7.2$ ) containing nalidixic acid $\left(25 \mathrm{mg} \mathrm{l}^{-1}\right)$, nystatin $\left(50 \mathrm{mg} \mathrm{l}^{-1}\right)$ and cycloheximide $\left(50 \mathrm{mg} \mathrm{l}^{-1}\right)$ to repress growth of Gramnegative bacteria and fungi. The plates were incubated at $28{ }^{\circ} \mathrm{C}$ for $4-6$ weeks until the outgrowth of endophytic actinomycetes was discerned. Colonies originating from leaf segments were selected and pure cultures were obtained by repeated streaking on medium YIM 38 [10 g malt extract, $4 \mathrm{~g}$ yeast extract, $4 \mathrm{~g}$ glucose, vitamin mixture (containing $0.5 \mathrm{mg}$ each of thiamine- $\mathrm{HCl}$, riboflavin, niacin, pyridoxine- $\mathrm{HCl}$, inositol, calcium pantothenate and $p$-aminobenzoic acid and $0.25 \mathrm{mg}$ biotin), $20 \mathrm{~g}$ agar; $\mathrm{pH}$ 7.2] (Jiang et al., 2007). Purified strain YIM $68255^{\mathrm{T}}$ was maintained on tryptic soy agar slants at $4{ }^{\circ} \mathrm{C}$ and as $20 \%(\mathrm{v} / \mathrm{v})$ glycerol suspensions at $-80{ }^{\circ} \mathrm{C}$.

Extraction of genomic DNA, PCR amplification and sequencing of the $16 \mathrm{~S}$ rRNA gene were carried out as described by $\mathrm{Li}$ et al. (2007). Multiple alignments with sequences of the most closely related actinobacteria were carried out using the program CLUSTAL_X 1.8 (Thompson et al., 1997). Phylogenetic trees were constructed by the neighbour-joining (Saitou \& Nei, 1987), maximum-parsimony (Fitch, 1971) and maximum-likelihood (Felsenstein, 1981) tree-making algorithms by using the software packages MEGA version 5.0 (Tamura et al., 2011). The stability of relationships was assessed by performing bootstrap analyses with 1000 resamplings
(Felsenstein, 1985). The values for sequence similarity among the closest strains were determined using the EzTaxon server (Chun et al., 2007). Levels of DNA-DNA relatedness were determined according to the optical renaturation method (De Ley et al., 1970; Huß et al., 1983; Jahnke, 1992). The G+C content of the genomic DNA was determined by using the HPLC method (Mesbah et al., 1989).

An almost complete $16 \mathrm{~S}$ rRNA gene sequence (1515 bp) of strain YIM $68255^{\mathrm{T}}$ was used for phylogenetic analysis with sequences of members of the family Micromonosporaceae. The highest sequence similarities $(\geqslant 97.0 \%)$ were between strain YIM $68255^{\mathrm{T}}$ and members of the genera Micromonospora, Actinoplanes, Asanoa, Dactylosporangium, Couchioplanes, Salinispora, Spirilliplanes, Jishengella, Actinaurispora, Polymorphospora and Plantactinospora (97.0-99.1\%). Despite these high 16S rRNA gene sequence similarities, strain YIM $68255^{\mathrm{T}}$ clustered with P. mayteni YIM $61359^{\mathrm{T}}$ (99.1 \% similarity) and A. siamensis $\mathrm{CM} 2-8^{\mathrm{T}}(97.8 \%$ similarity) after phylogenetic analysis of the 16S rRNA gene sequences (Fig. 1; Figs S1 and S2, available in IJSEM Online). P. mayteni YIM $61359^{\mathrm{T}}$ and $A$. siamensis $\mathrm{CM} 2-8^{\mathrm{T}}$ exhibited $97.8 \% 16 \mathrm{~S}$ rRNA gene sequence similarity to each other. The phylogenetic results clearly demonstrated that strain YIM $68255^{\mathrm{T}}$ was more closely related to P. mayteni YIM $61359^{\mathrm{T}}$ and A. siamensis CM2- $8^{\mathrm{T}}$ than other members of the family Micromonosporaceae. The levels of DNA-DNA relatedness between strain YIM $68255^{\mathrm{T}}$ and $P$. mayteni $\mathrm{YIM} 61359^{\mathrm{T}}$ and A. siamensis $\mathrm{CM} 2-8^{\mathrm{T}}$ were $42.7 \pm 1.3 \%$ and $24.7 \pm 0.9 \%$, respectively. P. mayteni YIM $61359^{\mathrm{T}}$ and $A$. siamensis $\mathrm{CM} 2-8^{\mathrm{T}}$ shared a DNA relatedness value of $31.3 \pm 1.2 \%$. These values were well below the $70 \%$ cut-off point for recognition of genomic species (Wayne et al., 1987), thus suggesting that strain YIM $68255^{\mathrm{T}}$, P. mayteni YIM $61359^{\mathrm{T}}$ and A. siamensis $\mathrm{CM} 2-8^{\mathrm{T}}$ represent different species. The DNA G $+\mathrm{C}$ content of strain YIM $68255^{\mathrm{T}}$ was $73.0 \mathrm{~mol} \%$.

Gram staining was carried out by using the standard Gram stain and cell motility was established by the development of turbidity throughout a tube containing semi-solid medium (Leifson, 1960). Cultural characteristics of strain YIM $68255^{\mathrm{T}}$ were recorded on ISP (International Streptomyces Project) media (Shirling \& Gottlieb, 1966), Czapek's agar, potato-glucose agar (PDA) and nutrient agar prepared as described by Dong \& Cai (2001). The colony colours were determined using the ISCC-NBS colour charts (Kelly, 1964). Microscopic observations of mycelia and spores of strain YIM $68255^{\mathrm{T}}$ grown on ISP 2 medium for $3-7$ weeks at $28{ }^{\circ} \mathrm{C}$ were made by light microscopy ( $\mathrm{BH} 2$; Olympus) and scanning electron microscopy (Quanta 200; FEI). Growth was tested at 4, $10,15,20,28,37,40,45$ and $55{ }^{\circ} \mathrm{C}$ on ISP 2 medium by 
incubating the cultures for 35 days. The ability of the strain

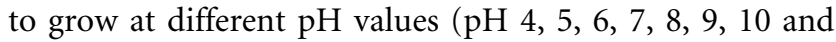
11 , using the buffer system described by $\mathrm{Xu}$ et al., 2005) and $\mathrm{NaCl}$ concentrations $(0,1,2,3,4,5,7,10,12,15$ and $20 \%$, w/v) was examined at $28{ }^{\circ} \mathrm{C}$ for 35 days. Catalase, oxidase and gelatinase activities, starch hydrolysis, nitrate reduction and urease were assessed as described by Smibert \& Krieg (1994). Media and procedures used for the determination of other physiological characteristics, carbon source utilization and acid production from carbohydrates were those described by Gordon et al. (1974).

Strain YIM $68255^{\mathrm{T}}$ was an aerobic, non-motile, Grampositive actinomycete that formed well-developed substrate mycelium, but no aerial mycelium. Smooth-surfaced spores were borne singly on the substrate hyphae (Fig. 2). Strain YIM $68255^{\mathrm{T}}$ grew well on ISP 2, ISP 3, PDA, nutrient agar and Czapek's agar, with moderate growth on ISP 4 medium and poor growth on ISP 5 medium. No soluble pigments were produced on any of the test media. The colour of colonies was orange-red before 6 weeks, and then brown on ISP 2, ISP 3, ISP 4, ISP 5 and PDA media, but orange-yellow before 5 weeks and then black on Czapek's agar and orange-yellow on nutrient agar. Strain YIM $68255^{\mathrm{T}}$ could grow at $10-45{ }^{\circ} \mathrm{C}$, at $\mathrm{pH} 5-10$ (optimum $\mathrm{pH} 7$ ) and in the presence of $0-3 \%(\mathrm{w} / \mathrm{v})$ $\mathrm{NaCl}$, but not in $4 \% \mathrm{NaCl}$. Detailed physiological and biochemical characteristics of strain YIM $68255^{\mathrm{T}}$ are given in the species description and Table 1.

The freeze-dried cells used for chemotaxonomic analyses were obtained from cultures grown in tryptic soy broth on a rotary shaker at $28{ }^{\circ} \mathrm{C}$ for 21 days. Amino acid and sugar analyses of whole-cell hydrolysates were performed according to the procedures described by Hasegawa et al. (1983); Lechevalier \& Lechevalier (1970) and Tang et al. (2009). Polar lipids were extracted, examined by two-dimensional TLC and identified using previously described procedures (Minnikin et al., 1979; Collins \& Jones, 1980). Menaquinones were isolated according to Collins et al. (1977) and

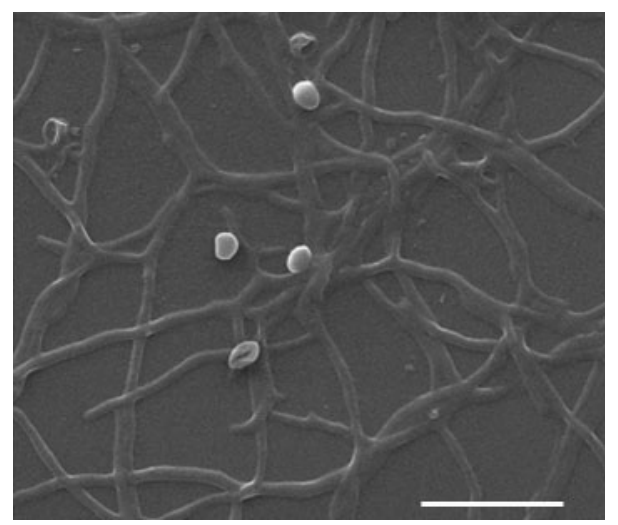

Fig. 2. Scanning electron micrograph of strain YIM $68255^{\top}$ grown on ISP 2 medium for 7 weeks at $28^{\circ} \mathrm{C}$. Bar, $5 \mu \mathrm{m}$. separated by HPLC (Tamaoka et al., 1983). Cellular fatty acids were extracted, methylated and analysed by using the Sherlock Microbial Identification System (MIDI) according to the manufacturer's instructions. Fatty acid methyl esters were analysed by using the Microbial Identification software package (Sherlock Version 6.1; MIDI database TSBA6).

The peptidoglycan of isolate YIM $68255^{\mathrm{T}}$ contained mesodiaminopimelic acid, whereas the whole-cell sugars detected were arabinose, galactose, glucose, mannose, xylose and rhamnose. The predominant menaquinones were MK-10 $\left(\mathrm{H}_{6}\right) \quad(59.6 \%)$, MK-10 $\left(\mathrm{H}_{8}\right) \quad(16.1 \%)$, MK$9\left(\mathrm{H}_{6}\right)(10.9 \%)$ and MK-10 $\left(\mathrm{H}_{4}\right)(6.9 \%)$, with MK-9 $\left(\mathrm{H}_{8}\right)$ $(3.3 \%)$, MK- $9\left(\mathrm{H}_{4}\right)(1.8 \%)$ and $\mathrm{MK}-10\left(\mathrm{H}_{2}\right)(1.3 \%)$ as minor components. Phosphatidylethanolamine, diphosphatidylglycerol and phosphatidylinositol were detected (Fig. S3), corresponding to phospholipid type PII of Lechevalier et al. (1977). The major fatty acids were anteiso- $\mathrm{C}_{17: 0}(26.20 \%)$, iso- $\mathrm{C}_{16: 0}(22.75 \%)$, iso- $\mathrm{C}_{15: 0}$ $(12.71 \%)$, iso- $\mathrm{C}_{17: 0}(8.99 \%)$ and anteiso- $\mathrm{C}_{15: 0}(8.07 \%)$. The chemotaxonomic properties (whole-cell sugars, predominant menaquinones and fatty acid type) of the three strains, YIM $68255^{\mathrm{T}}$, P. mayteni YIM $61359^{\mathrm{T}}$ and $A$. siamensis CM2-8 ${ }^{\mathrm{T}}$, were very similar to each other in this study (Table 2). Arabinose, galactose, glucose, mannose, xylose and rhamnose were detected as whole-cell sugars (Fig. S4). The major fatty acids were iso- $\mathrm{C}_{15: 0}$, anteiso$\mathrm{C}_{17: 0}$, iso- $\mathrm{C}_{16: 0}$ and anteiso- $\mathrm{C}_{15: 0}$. The menaquinone components of these three strains were not significantly different, except that MK-9 $\left(\mathrm{H}_{6}\right)$ was detected in $A$. siamensis $\mathrm{CM} 2-8^{\mathrm{T}}$ and strain YIM $68255^{\mathrm{T}}$ as a predominant menaquinone (Table 2).

On the basis of the phenotypic, genotypic and phylogenetic data presented here, strain YIM $68255^{\mathrm{T}}$ differed from its closest relatives, P. mayteni YIM $61359^{\mathrm{T}}$ and A. siamensis $\mathrm{CM} 2-8^{\mathrm{T}}$. It could grow at $10-45^{\circ} \mathrm{C}$ and $\mathrm{pH} 5-10$ and was positive for catalase production and Tween 80 hydrolysis. DGalactose, inositol, lactose and mannitol were not used as sole carbon sources. L-Hydroxyproline was used as a sole nitrogen source. Furthermore, the levels of DNA-DNA relatedness of strain YIM $68255^{\mathrm{T}}$ with $P$. mayteni $\mathrm{YIM} 61359^{\mathrm{T}}$ and $A$. siamensis $\mathrm{CM} 2-8^{\mathrm{T}}$ were $42.7 \pm 1.3 \%$ and $24.7 \pm 0.9 \%$, respectively. Based on the data presented, it is proposed that strain YIM $68255^{\mathrm{T}}$ should be recognized as a novel species of Plantactinospora, for which the name Plantactinospora endophytica sp. nov. is proposed. Furthermore, the results of phylogenetic analysis showed that the relationship between these three strains, YIM $68255^{\mathrm{T}}, P$. mayteni $\mathrm{YIM} 61359^{\mathrm{T}}$ and A. siamensis $\mathrm{CM} 2-8^{\mathrm{T}}$, was much closer than with other members of the family Micromonosporaceae and their chemotaxonomic characteristics were very similar to each other. All three strains had the same peptidoglycan diagnostic amino acid (meso-diaminopimelic acid), whole-cell sugars (arabinose, galactose, glucose, mannose, xylose and rhamnose), polar lipid type (PII) and major fatty acids (iso- $\mathrm{C}_{15: 0}$, anteiso$\mathrm{C}_{17: 0}$, iso- $\mathrm{C}_{16: 0}$ and anteiso- $\mathrm{C}_{15: 0}$ ), and the predominant menaquinones were not significantly different. Based on our 
Table 1. Differential phenotypic characteristics of strain YIM $68255^{\top}$ and related strains

Strains: 1, YIM $68255^{\mathrm{T}}$; 2, P. mayteni YIM $61359^{\mathrm{T}}$; 3, A. siamensis CM2-8 ${ }^{\mathrm{T}}$. +, Positive; w, weakly positive; -, negative. Data are from this study, tested under the same conditions, unless indicated otherwise.

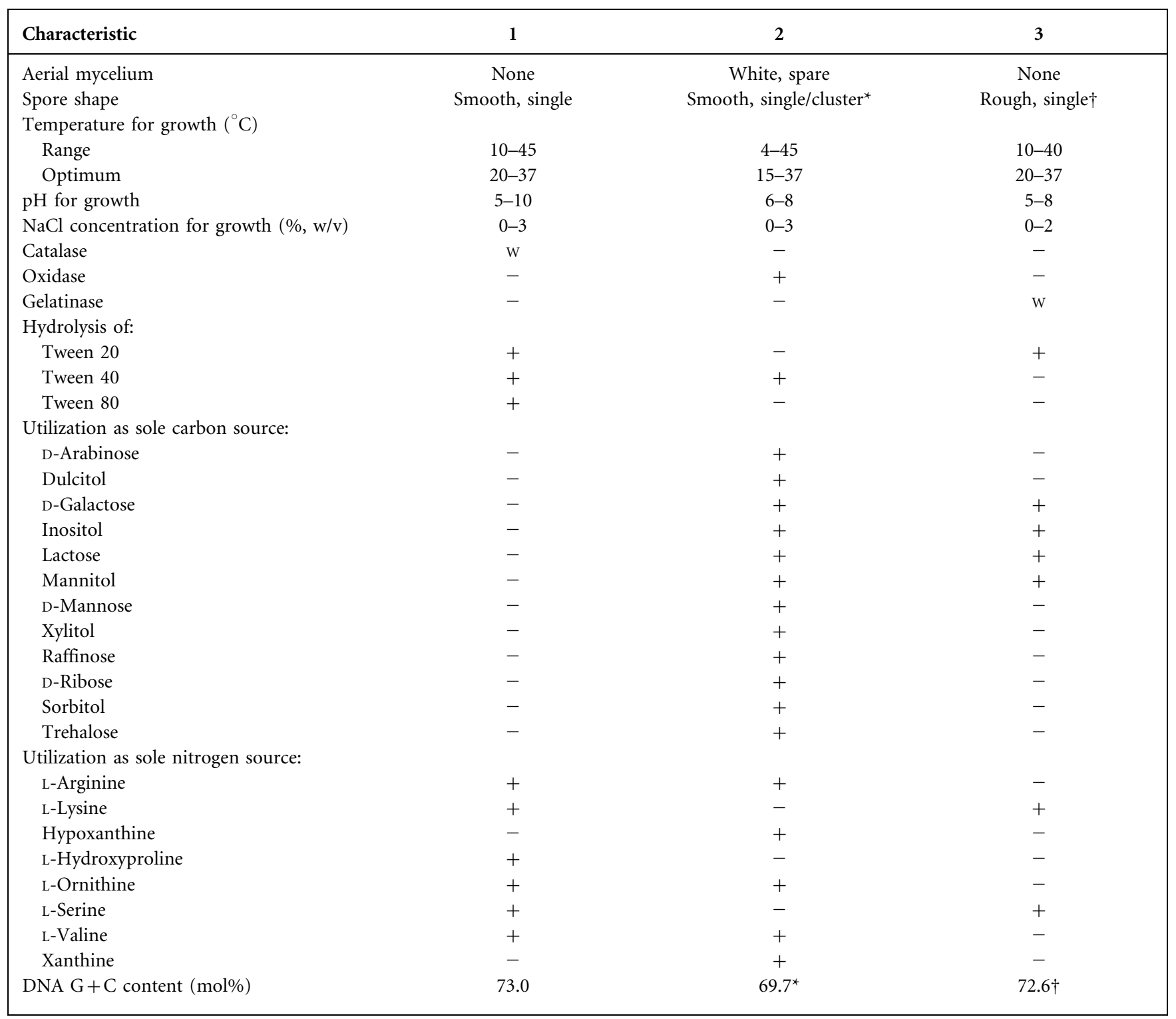

${ }^{*}$ Data from Qin et al. (2009).

$\dagger$ Data from Thawai et al. (2010).

data, the two genera Actinaurispora and Plantactinospora should be combined, and $A$. siamensis should be reclassified as Plantactinospora siamensis comb. nov. The descriptions of the genus Plantactinospora and P. mayteni are emended.

\section{Emended description of the genus Plantactinospora Qin et al. 2009}

The genus is as described by Qin et al. (2009), with the following emendations. Smooth/rough-surfaced spores are borne singly or in clusters. Arabinose, galactose, glucose, mannose, xylose and rhamnose are detected as whole-cell sugars. The phospholipid type is PII. The predominant menaquinone is $\mathrm{MK}-9\left(\mathrm{H}_{6}\right)$ or $\mathrm{MK}-10\left(\mathrm{H}_{6}\right)$. The major fatty acids are iso- $\mathrm{C}_{15: 0}$, anteiso- $\mathrm{C}_{17: 0}$, iso- $\mathrm{C}_{16: 0}$ and anteiso$\mathrm{C}_{15: 0}$. The DNA G+C content is $69.0-73.0 \mathrm{~mol} \%$.

\section{Emended description of Plantactinospora mayteni Qin et al. 2009}

The emended description of this species is based on that given by Qin et al. (2009), with the following supplements and changes. Utilizes inositol and xylitol as sole carbon sources, but not glycerol. L-Asparagine, L-alanine, glycine, 
Table 2. Chemotaxonomic characteristics that differentiate strain $\mathrm{YIM} 68255^{\top}$ from its closest relatives

Strains: 1, YIM $68255^{\mathrm{T}}$; 2, P. mayteni YIM $61359^{\mathrm{T}} ; 3$, A. siamensis $\mathrm{CM} 2-8^{\mathrm{T}}$. All data are taken from this study and all three strains have the same diagnostic amino acid in the peptidoglycan (meso-diaminopimelic acid), whole-cell sugars (arabinose, galactose, glucose, mannose, xylose, rhamnose) and polar lipid type (PII). -, Not detected.

\begin{tabular}{|c|c|c|c|}
\hline Characteristic & 1 & 2 & 3 \\
\hline $\begin{array}{l}\text { Predominant menaquinones } \\
(>5 \%)\end{array}$ & $\begin{array}{c}\text { MK-10 }\left(\mathrm{H}_{6}\right)(59.6 \%), \text { MK-10 }\left(\mathrm{H}_{8}\right) \\
(16.1 \%), \text { MK- } 9\left(\mathrm{H}_{6}\right)(10.9 \%) \\
\left.\text { MK-10( } \mathrm{H}_{4}\right)(6.9 \%)\end{array}$ & $\begin{array}{c}\left.\text { MK-10 }\left(\mathrm{H}_{6}\right)(49.4 \%), \text { MK-10( } \mathrm{H}_{8}\right) \\
\left.(26.6 \%), \text { MK-10( } \mathrm{H}_{4}\right)(11.2 \%), \\
\left.\text { MK-9( } \mathrm{H}_{6}\right)(7.5 \%)\end{array}$ & $\begin{array}{c}\text { MK- } 9\left(\mathrm{H}_{6}\right)(39.6 \%), \text { MK-10 }\left(\mathrm{H}_{6}\right) \\
(17.2 \%), \text { MK- } 9\left(\mathrm{H}_{8}\right)(8.5 \%), \\
\left.\text { MK-10( } \mathrm{H}_{8}\right)(6.6 \%)\end{array}$ \\
\hline \multicolumn{4}{|l|}{ Fatty acid (\%) } \\
\hline $\mathrm{C}_{16: 0}$ & 0.48 & 0.39 & 0.74 \\
\hline $\mathrm{C}_{17: 0}$ & 3.19 & 4.28 & 8.79 \\
\hline $\mathrm{C}_{18: 0}$ & 2.53 & 0.54 & 0.88 \\
\hline$C_{19: 0}$ & 1.06 & 0.40 & 0.73 \\
\hline $\mathrm{C}_{16: 1} 2-\mathrm{OH}$ & 2.20 & 1.98 & - \\
\hline $\mathrm{C}_{17: 1} \omega 8 c$ & 0.98 & 6.53 & 2.42 \\
\hline $\mathrm{C}_{18: 1} \omega 9 c$ & 1.26 & 1.08 & 0.41 \\
\hline iso- $\mathrm{C}_{14: 0}$ & 1.61 & 1.00 & 1.16 \\
\hline iso- $\mathrm{C}_{15: 0}$ & 12.71 & 18.18 & 23.37 \\
\hline iso- $\mathrm{C}_{16: 0}$ & 22.75 & 17.77 & 16.04 \\
\hline iso- $\mathrm{C}_{17: 0}$ & 8.99 & 4.65 & 11.87 \\
\hline iso- $\mathrm{C}_{18: 0}$ & 3.22 & 0.95 & 0.4 \\
\hline iso- $\mathrm{C}_{19: 0}$ & 0.38 & - & - \\
\hline iso- $\mathrm{C}_{15: 1} \mathrm{G}$ & 0.05 & 0.58 & - \\
\hline iso- $\mathrm{C}_{16: 1} \mathrm{G}$ & 1.19 & 1.08 & - \\
\hline anteiso- $\mathrm{C}_{15: 0}$ & 8.07 & 17.45 & 11.15 \\
\hline anteiso- $\mathrm{C}_{17: 0}$ & 26.2 & 20.37 & 17.38 \\
\hline anteiso- $\mathrm{C}_{19: 0}$ & 0.79 & - & - \\
\hline anteiso- $\mathrm{C}_{17: 1} \mathrm{~A}$ & 0.66 & 1.08 & - \\
\hline 10-methyl $C_{17: 0}$ & 0.58 & 0.68 & 3.93 \\
\hline 10-methyl $\mathrm{C}_{18: 0}$ & 0.21 & - & 0.28 \\
\hline Summed feature $6^{\star}$ & - & 0.45 & - \\
\hline Summed feature $9^{*}$ & 0.40 & 0.27 & 0.45 \\
\hline
\end{tabular}

*Summed features represent two or three fatty acids that cannot be separated by the Microbial Identification System. Summed feature 6 consisted of $\mathrm{C}_{19: 1} \omega 11 c$ and/or $\mathrm{C}_{19: 1} \omega 9 c$. Summed feature 9 consisted of iso- $\mathrm{C}_{17: 1} \omega 9 c$ and/or 10 -methyl- $\mathrm{C}_{16: 0}$.

hypoxanthine, L-ornithine, L-valine and xanthine are used as sole nitrogen sources, but not L-hydroxyproline, L-lysine or L-serine. Arabinose, galactose, glucose, mannose, xylose and rhamnose are detected as whole-cell sugars. Major fatty acids are anteiso- $\mathrm{C}_{17: 0}$, anteiso- $\mathrm{C}_{15: 0}$, iso- $\mathrm{C}_{15: 0}$, iso- $\mathrm{C}_{16: 0}$, $\mathrm{C}_{17: 1} \omega 8 c$ and iso- $\mathrm{C}_{17: 0}$.

\section{Description of Plantactinospora siamensis comb. nov.}

Plantactinospora siamensis (si.am.en'sis. N.L. fem. adj. siamensis of or pertaining to Siam, the old name for Thailand, the country of origin of the soil from which the type strain was isolated).

Basonym: Actinaurispora siamensis Thawai et al. 2010.

This description is based on that given by Thawai et al. (2010), with the following additions and changes. Inositol and sucrose can be utilized as sole carbon sources, but not dulcitol, D-mannose, sorbitol, trehalose or xylitol. Utilizes
L-alanine, L-asparagine, glycine, L-lysine and L-serine as sole nitrogen sources, but not L-arginine, L-hydroxyproline, hypoxanthine, L-ornithine, L-valine or xanthine. Arabinose, galactose, glucose, mannose, xylose and rhamnose are detected as whole-cell sugars.

The type strain is CM2-8 ${ }^{\mathrm{T}}\left(=\mathrm{JCM} 15677^{\mathrm{T}}=\mathrm{BCC} 34762^{\mathrm{T}}\right)$, isolated from temperate peat swamp forest soil in Chiang Mai Province, Thailand.

\section{Description of Plantactinospora endophytica sp. nov.}

Plantactinospora endophytica (en.do.phy'ti.ca. Gr. pref. endo within; Gr. n. phuton plant; L. fem. suff. -ica adjectival suffix used with the sense of belonging to; N.L. fem. adj. endophytica within plant, endophytic).

Aerobic, non-motile, Gram-positive actinomycete that forms well-developed substrate mycelium, but no aerial mycelium. Smooth-surfaced spores are borne singly on the 
substrate hyphae. Grows well on ISP 2, ISP 3, PDA, nutrient agar and Czapek's agar, with moderate growth on ISP 4 medium and poor growth on ISP 5 medium. No soluble pigments are produced on the media tested. The colour of colonies is orange-red before 6 weeks, and then brown on ISP 2, ISP 3, ISP 4, ISP 5 and PDA media, orange-yellow before 5 weeks and then black on Czapek's agar, and orange-yellow on nutrient agar. Grows at 10$45{ }^{\circ} \mathrm{C}$, at $\mathrm{pH}$ 5-10 (optimum pH 7) and in the presence of $0-3 \%(\mathrm{w} / \mathrm{v}) \mathrm{NaCl}$, but not in $4 \% \mathrm{NaCl}$. Negative for production of oxidase, gelatinase, urease and $\mathrm{H}_{2} \mathrm{~S}$. Negative for milk coagulation and peptonization, starch hydrolysis and nitrate reduction. Weakly positive for production of catalase. Tweens 20, 40, 80 and cellulose are hydrolysed. Utilizes cellobiose, D-fructose, glucose, maltose, L-rhamnose, sucrose and D-xylose as sole carbon sources. DArabinose, dulcitol, glycerol, D-galactose, inositol, lactose, D-mannose, mannitol, raffinose, D-ribose, sorbitol, trehalose and xylitol are not utilized. L-Alanine, L-arginine, Lasparagine, glycine, L-hydroxyproline, L-lysine, L-ornithine, $\mathrm{L}$-serine and L-valine are used as sole nitrogen sources, but not hypoxanthine or xanthine. The polar lipids are phosphatidylethanolamine, diphosphatidylglycerol, phosphatidylinositol and several unknown lipids. The cell wall contains meso-diaminopimelic acid and the whole-cell sugars detected are arabinose, galactose, glucose, mannose, xylose and rhamnose. The predominant menaquinones are MK-10 $\left(\mathrm{H}_{6}\right)$, MK-10 $\left(\mathrm{H}_{8}\right)$, MK-9 $\left(\mathrm{H}_{6}\right)$ and MK-10 $\left(\mathrm{H}_{4}\right)$. Major fatty acids are anteiso- $\mathrm{C}_{17: 0}$, iso- $\mathrm{C}_{16: 0}$, iso- $\mathrm{C}_{15: 0}$, anteiso- $\mathrm{C}_{15: 0}$ and iso- $\mathrm{C}_{17: 0}$.

The type strain, YIM $68255^{\mathrm{T}}\left(=\mathrm{DSM} 45387^{\mathrm{T}}=\right.$ CCTCC AA $209047^{\mathrm{T}}$ ), was isolated from leaves of Camptotheca acuminata Decne. collected in Yunnan Province, southwest China. The DNA G $+\mathrm{C}$ content of the type strain is $73.0 \mathrm{~mol} \%$.

\section{Acknowledgements}

The authors are grateful to Professor Chitti Thawai from King Mongkut's Institute of Technology Ladkrabang, Thailand, for kindly providing the reference type strain A. siamensis CM2 $-8^{\mathrm{T}}$ and Dr Paul Meyers from University of Cape Town, South Africa for his helpful comments on our manuscript. This research was supported by the National Basic Research Program of China (2010CB833801), the National Natural Science Foundation of China (no. U0932601) and the Basic Research Foundation of Yunnan University (no. 2010ZD001). W.-J. L. was also supported by 'Hundred Talents Program' of the Chinese Academy of Sciences.

\section{References}

Chun, J., Lee, J.-H., Jung, Y., Kim, M., Kim, S., Kim, B. K. \& Lim, Y. W. (2007). EzTaxon: a web-based tool for the identification of prokaryotes based on 16 S ribosomal RNA gene sequences. Int J Syst Evol Microbiol 57, 2259-2261.

Collins, M. D. \& Jones, D. (1980). Lipids in the classification and identification of coryneform bacteria containing peptidoglycans based on 2,4-diaminobutyric acid. J Appl Bacteriol 48, 459-470.
Collins, M. D., Pirouz, T., Goodfellow, M. \& Minnikin, D. E. (1977). Distribution of menaquinones in actinomycetes and corynebacteria. J Gen Microbiol 100, 221-230.

De Ley, J., Cattoir, H. \& Reynaerts, A. (1970). The quantitative measurement of DNA hybridization from renaturation rates. Eur $J$ Biochem 12, 133-142.

Dong, X. Z. \& Cai, M. Y. (2001). Manual of Systematics and Identification of General Bacteria. Beijing: Science Press (in Chinese).

Felsenstein, J. (1981). Evolutionary trees from DNA sequences: a maximum likelihood approach. J Mol Evol 17, 368-376.

Felsenstein, J. (1985). Confidence limits on phylogenies: an approach using the bootstrap. Evolution 39, 783-791.

Fitch, W. M. (1971). Toward defining the course of evolution: minimum change for a specific tree topology. Syst Zool 20, 406-416.

Gordon, R. E., Barnett, D. A., Handerhan, J. E. \& Pang, C. H.-N. (1974). Nocardia coeliaca, Nocardia autotrophica, and the nocardin strain. Int J Syst Bacteriol 24, 54-63.

Hasegawa, T., Takizawa, M. \& Tanida, S. (1983). A rapid analysis for chemical grouping of aerobic actinomycetes. J Gen Appl Microbiol 29, 319-322.

Huß, V. A. R., Festl, H. \& Schleifer, K. H. (1983). Studies on the spectrophotometric determination of DNA hybridization from renaturation rates. Syst Appl Microbiol 4, 184-192.

Jahnke, K. D. (1992). BASIC computer program for evaluation of spectroscopic DNA renaturation data from Gilford System 2600 spectrophotometer on a PC/XT/AT type personal computer. J Microbiol Methods 15, 61-73.

Jiang, Y., Tang, S. K., Wiese, J., Xu, L. H., Imhoff, J. F. \& Jiang, C. L. (2007). Streptomyces hainanensis sp. nov., a novel member of the genus Streptomyces. Int J Syst Evol Microbiol 57, 2694-2698.

Kelly, K. L. (1964). Inter-Society Color Council-National Bureau of Standards Color Name Charts Illustrated with Centroid Colors. Washington, DC: US Government Printing Office.

Lechevalier, M. P. \& Lechevalier, H. A. (1970). Chemical composition as a criterion in the classification of aerobic actinomycetes. Int J Syst Bacteriol 20, 435-443.

Lechevalier, M. P., De Bièvre, C. \& Lechevalier, H. A. (1977). Chemotaxonomy of aerobic actinomycetes: phospholipid composition. Biochem Syst Ecol 5, 249-260.

Leifson, E. (1960). Atlas of Bacterial Flagellation. London: Academic Press.

Li, W. J., Xu, P., Schumann, P., Zhang, Y. Q., Pukall, R., Xu, L. H., Stackebrandt, E. \& Jiang, C. L. (2007). Georgenia ruanii sp. nov., a novel actinobacterium isolated from forest soil in Yunnan (China), and emended description of the genus Georgenia. Int J Syst Evol Microbiol 57, 1424-1428.

Li, J., Zhao, G. Z., Chen, H. H., Wang, H. B., Qin, S., Zhu, W. Y., Xu, L. H., Jiang, C. L. \& Li, W. J. (2008). Antitumour and antimicrobial activities of endophytic streptomycetes from pharmaceutical plants in rainforest. Lett Appl Microbiol 47, 574-580.

Mesbah, M., Premachandran, U. \& Whitman, W. B. (1989). Precise measurement of the $\mathrm{G}+\mathrm{C}$ content of deoxyribonucleic acid by highperformance liquid chromatography. Int J Syst Bacteriol 39, 159-167.

Minnikin, D. E., Collins, M. D. \& Goodfellow, M. (1979). Fatty acid and polar lipid composition in the classification of Cellulomonas, Oerskovia and related taxa. J Appl Bacteriol 47, 87-95.

Qin, S., Li, J., Zhang, Y. Q., Zhu, W. Y., Zhao, G. Z., Xu, L. H. \& Li, W. J. (2009). Plantactinospora mayteni gen. nov., sp. nov., a member of the family Micromonosporaceae. Int J Syst Evol Microbiol 59, 2527-2533.

Saitou, N. \& Nei, M. (1987). The neighbor-joining method: a new method for reconstructing phylogenetic trees. Mol Biol Evol 4, 406-425. 
Shirling, E. B. \& Gottlieb, D. (1966). Methods for characterization of Streptomyces species. Int J Syst Bacteriol 16, 313-340.

Smibert, R. M. \& Krieg, N. R. (1994). Phenotypic characterization. In Methods for General and Molecular Bacteriology, pp. 607-654. Edited by P. Gerhardt, R. G. E. Murray, W. A. Wood \& N. R. Krieg. Washington, D.C.: American Society for Microbiology.

Tamaoka, J., Katayama-Fujimura, Y. \& Kuraishi, H. (1983). Analysis of bacterial menaquinone mixtures by high performance liquid chromatography. J Appl Bacteriol 54, 31-36.

Tamura, K., Peterson, D., Peterson, N., Stecher, G., Nei, M. \& Kumar, S. (2011). MEGA5: molecular evolutionary genetics analysis using maximum likelihood, evolutionary distance, and maximum parsimony methods. Mol Biol Evol 28, 2731-2739.

Tang, S. K., Wang, Y., Chen, Y., Lou, K., Cao, L. L., Xu, L. H. \& Li, W. J. (2009). Zhihengliuella alba sp. nov., and emended description of the genus Zhihengliuella. Int J Syst Evol Microbiol 59, 2025-2031.
Thawai, C., Tanasupawat, S., Suwanborirux, K. \& Kudo, T. (2010). Actinaurispora siamensis gen. nov., sp. nov., a new member of the family Micromonosporaceae. Int J Syst Evol Microbiol 60, 1660-1666.

Thompson, J. D., Gibson, T. J., Plewniak, F., Jeanmougin, F. \& Higgins, D. G. (1997). The CLUSTAL_X windows interface: flexible strategies for multiple sequence alignment aided by quality analysis tools. Nucleic Acids Res 25, 4876-4882.

Wayne, L. G., Brenner, D. J., Colwell, R. R., Grimont, P. A. D., Kandler, O., Krichevsky, M. I., Moore, L. H., Moore, W. E. C., Murray, R. G. E. \& other authors (1987). International Committee on Systematic Bacteriology. Report of the ad hoc committee on reconciliation of approaches to bacterial systematics. Int J Syst Bacteriol 37, 463-464.

Xu, P., Li, W. J., Tang, S. K., Zhang, Y. Q., Chen, G. Z., Chen, H. H., Xu, L. H. \& Jiang, C. L. (2005). Naxibacter alkalitolerans gen. nov., sp. nov., a novel member of the family 'Oxalobacteraceae' isolated from China. Int J Syst Evol Microbiol 55, 1149-1153. 